\title{
THE NEW YORK AFRO-AMERICAN'S STRUGGLE FOR POLITICAL RIGHTS AND THE EMERGENCE OF POLITICAL RECOGNITION,
} I865-1900

In this periodical, in a previous article covering the period 1777-1865, it was revealed that many New York Afro-Americans had refused to view with apathy, or even equanimity, their changed political status following the end of the American Revolution. ${ }^{1}$ Under New York State's 1777 Constitution, freed Black Americans had held equal suffrage rights with whites, but shortly thereafter discovered that most of these voting rights were to be whittled down, initially by the DemocraticRepublicans. ${ }^{2}$ Many New York Afro-Americans, individually and in concert reacted to the watering down of their political rights by consistently petitioning the New York State Legislature to restore their political rights as held under the 1777 Constitution. However, the dominant group's stereotype of the Colored American prevailed since petition after petition failed to convince, first the legislators and later the white voters that they should restore equal political status to Afro-Americans in New York.

Although, after the Civil War there was a peripheral upsurge in national awareness of the discrepancy in voting rights between Black and White, the Colored American had to wait until passage of the 15th Amendment to the Federal Constitution (1870), before the New York State Legislature and the voters conceded to Afro-Americans a franchise similar to that enjoyed by the foreign born. Back in 1826 all property qualifications for Whites had been abolished and White residence requirements were reduced to one year. However, AfroAmericans were excluded from this change; in addition to special property requirements, they had to meet a three year residence requirement in order to vote.

This paper deals with some aspects of the post-bellum period in American history which did reveal a temporary renewal of national interest in the freedman's suffrage question. Our primary emphasis will be on New York's Colored Americans. After New York's Afro-

1 H. D. Bloch, "The New York Negro's Battle for Political Rights, 1777-1865", in: International Review of Social History, Vol. 9, (1964), Part I.

2 New York Spectator, April 29, 1809. 
Americans did obtain equal suffrage rights (citizenship, and voting rights), many soon discovered that they were still without equal rights, such as: non-segregation in public accommodations, schools, cemeteries, churches, housing, hospitals, union membership, etc. Many Black Americans discovered that politicians were able to curtail newly won political rights through various political subterfuges, thereby reducing the effects of political equality.

\section{UNEQUAL POLITICAL RIGHTS PERSIST, 1865-1870}

With respect to Afro-American suffrage, termination of the internecine conflict revealed the existence of polarity within the Republican organization. At one extreme were the Radical Republicans and at the other President Andrew Johnson. Ostensibly, both organizations sought to resolve the issue of Afro-American suffrage. The Radical Republicans were led by such men as Thaddeus Stevens, Charles Sumner, etc. Stevens was the "unquestioned leader of the House of Representatives from July 4, 1861, when it was assembled at the call of Lincoln, until his death", in 1868. Also, he was chairman of the Reconstruction Committee. ${ }^{1}$ Charles Sumner was a senator from Massachusetts. This group contended that Colored American suffrage should be used as one basis for congressional representation in Washington. After the Civil War, the Radical Republicans feared that the new freedmen would be deprived of their citizenship and voting rights. The Radicals suspected that the Southern States would use freed AfroAmericans now counted as whole men instead of the three-fifths of men as the basis for representation, thus increasing Southern representation by about one-fourth in Congress, ${ }^{2}$ without extending the vote to AfroAmericans. To forestall this possibility, the use of the total male population as the basis for apportionment of United States Congressmen, the Radicals sought to restrict Congressional representation to the number of actually registered voters. This political move was intended to sway support in favor of universal manhood suffrage. ${ }^{3}$ The Radical Republicans' anticipation of political manipulation realized in the Elk v. Wilkins case, ${ }^{4}$ which stated that:

"Slavery having been abolished, and the persons formerly held as slaves made citizens, this clause fixing the apportionment of

1 S. W. McCall, Thaddeus Stevens (N.Y., 1899), preface.

2 H. Minor, The Story of the Democratic Party (N.Y., 1928), p. 295.

${ }^{3}$ D. S. Alexander, Political History of the State of New York (N.Y., 1909), III, p. 136.

4 Elkins v. Wilkins, 112 U.S. 94, p. 102 (1884). 
representatives has abrogated so much of... [Art. I, par. 2, Clause 3 ] of the original Constitution [which] counted only three-fifths of such persons [slaves, as to alter the number used in apportionment of the House of Representatives]."1

Although Andrew Johnson came from Tennessee, which had joined the rebellion, he displayed unusual loyalty to the Union during the internecine conflict. This loyalty won him the nomination for the vice-presidency. When Johnson took office on April 15, 1865, the Radical Republicans thought that they would now realize the punishment of their late enemies. It was Johnson who stated that "I hold treason is a crime and must be punished. Treason must be made infamous and traitors must be impoverished."2 However, the Radicals soon discovered that they had misunderstood Johnson's views on politics since treason and traitors was restricted only to those he termed responsible for secession, or members of the official and higher classes. It did not extend to the states nor to the masses of people of the seceded states. ${ }^{3}$ The realization by the Radicals that Johnson's plan was not to punish the southern states led them to label the program "gradualism" and pro-Southern. In addition to pointing up that Johnson's program was to favorable to the restoration of Southern States rights, they pointed to his vetoing the 1866 Civil Rights Act, his advocacy of leaving the Afro-American suffrage issue to the future action of the States, etc. ${ }^{4}$

Johnson's plan of reconstruction was contained in two papers and may be summarized as follows: (1) Repeal of secession, or granting of amnesty to all the rebellious states, and (2) a Presidential order, originally applicable only to North Carolina, later applied by successive orders to all the rebellious states. ${ }^{5}$ The North Carolina order was based on the Constitutional clause which provided that the United States should guarantee to each State a republican form of government. This order provided for the appointment of a provisional governor of North Carolina and the provisional governor was to prescribe the rules for "convening a convention." The delegates to the convention were to be chosen from the loyal people of the State. These delegates were to amend the state constitution, and to adopt a republican form of government. The loyal people included only those granted amnesty, and these were restricted to qualified voters in accord with the laws in

1 Ibid., p. 102.

2 Minor, p. 294.

3 Ibid., pp. 294-295.

4 Tribune Almanac and Political Register for 1866 (N.Y., 1858-1889), p. 44.

s McCall, p. 246. 
force at the time of the secession. The irony of Johnson's plan was that he imposed the reconstruction upon white secessionists and at the same time put them in control. (This enabled them to reestablish the Civil War hierarchy since they remained in the majority. It may be recalled that Afro-American freedmen were denied the vote before the war started and thus by proclamation were excluded in establishing the new government under the Johnson plan.) This Southern majority was given the power to establish a new Constitution and more important to set the conditions of suffrage and other fundamental rights. The new legislatures arising from Johnson's plan speedily proceeded to enact laws expressly aimed at curtailing the rights and privileges of the Afro-American. In turn these Southern enactments produced a rift between the President and the Congress. ${ }^{1}$ Concretely speaking, Mississippi passed laws requiring its officers to report to probate courts all free Afro-Americans under the age of 18 , whose parents were without means to support them, or refused to do so. The court was to make the decision in each case, and decide whether the youngster was to be apprenticed. Furthermore the Court in choosing the master for the new apprentice was to give preference to the apprentice's former owner. New laws little different from the old "runaway-slave-laws" were enacted to insure that the new apprentice was tied to his old master as when he was a slave. Thus severe penalties were enacted in the instance of the "apprentice" who ran away. The same legislature provided for Blacks over 18 years of age; all free Blacks found with no lawful employment or business were to be viewed as vagrants subject to a heavy fine. If the "vagrant" was unable to pay the fine he was "hired out", again preferably to his old master, for a term sufficient to produce the amount of the fine. ${ }^{2}$ Laws similar to those passed in Mississippi were enacted in South Carolina, Alabama, Florida, etc. ${ }^{3}$ At a time when poverty was so prevalent among both Blacks and Whites very few could prove judicially that they had the means to support themselves so how could they establish that they could support their offspring.

Since the Republicans, in the 1866 election, gained control over both houses in the Congress, it appeared that the Extreme Radicals held the upper hand in the legislative branch of our national government. This view seemed even more plausible since the Congress over-rode the Presidential veto of the 1866 Civil Rights Act, ${ }^{4}$ and to forestall the

1 Ibid., pp. 247-249.

2 Mississippi, Act of November 24, 1865, as cited by McCall.

3 McPherson, The Political History of the U.S. of America during the Reconstruction (2nd ed., Washington, D.C., 1875), p. 21.

4 New York Times, June 18, 1968. A 102 years after its enactment, the United 
Southerners finding possible loop-holes in the Act, the 14th Amendment was passed and it was ratified by the States in $1868 .{ }^{1}$ Our emphasis on the Radical Republican program should not be taken to mean that there was no dissension within the party. Indicative of differences of opinion in the party was evidenced by New York's 1865 Republican State Convention held at Syracuse when it resolved to recognize the jurisdiction of the States over local affairs. There was, however, unanimity in principle that the spirit of equal and impartial justice should be exercised in order to raise and perpetuate the full rights of citizenship to all people. ${ }^{2}$ In accord with the previous statement, convention delegates recognized that New York State had been remiss with regard to granting equal suffrage to its own Afro-American population. ${ }^{3}$ Still what Congressional action did take place, passage of the 1866 Civil Rights Act, the 14th Amendment, was intended as a challenge to the Southern Whites' position on the equal suffrage question. Many New York Afro-Americans recognized Congress' intent when they memorialized the Congress to table New York's Senator James G. Blaine's proposal, ${ }^{4}$ which was to be incorporated as section 2 of the 14th amendment. It read:

"Representatives shall be apportioned among the several States according to their respective numbers, counting the whole number of persons in each State, excluding Indians not taxed. But when the right to vote at any election for the choice of electors for President and Vice-president of the United States, Representatives in Congress, the Executive and Judicial Officers of a State, or members of the legislature thereof, is denied to any of the male citizens of the United States, or in any way abridged, except for participation in rebellion, or other crime, the basis of representation therein shall be reduced in proportion which the number of such male citizens shall bear to the whole number of male citizens 21 years of age in such State."

Ostensibly, Congress had the power to force States to extend the suffrage right to all citizens of the United States, unless the State was

States Supreme Court cited the 1866 Civil Rights Act as being constitutional. The 1866 Act goes beyond the 1968 Civil Rights Act since the former bans bias in "purchase, lease, sell, hold and convey real and personal property".

1 Congressional Globe, 39 Cong., 1 sess., appendix, ch. XXXI, pp. 315, 316.

2 American Cyclopaedia and Register of Important Events (N.Y., 1865), pp. 614-615.

3 New York Tribune, July 8, 1865.

4 House Miscellaneous Documents, No 109, 39 Cong., 1 sess.; James G. Blaine, Twenty Years of Congress (Norwich, Conn., 1884-1886). 
willing to forego apportionment based on the whole number. The Supreme Court's interpretation of this section proved favorable to States Rights. Thus, with regard to reduction of State Representation, the Supreme Court denied a petition to curtail the State of Virginia from sending its quota of representation inspite of its violation of Sec. 2 of the 14th Amendment. The Court reasoned as follows:

"Questions relating to the apportionment of representatives among the several States are political in their nature, and reside exclusively within the determination of Congress..."1

Utilizing the United States Supreme Court's decision, a United States District Court was obliged to dismiss an action for damages against the Virginia Secretary of State for the latter's refusal to certify an AfroAmerican plaintiff as a candidate for the office of Congressman at large, inasmuch as the Black plaintiff's case rested on the theory that the apportionment act of Congress and the Redistribution Act of Virginia, by failing to take into account the disenfranchisement of 60 percent of the State's voters, occasioned by the poll tax, were both invalid, and that Virginia according to Sec. 2. of the 14th Amendment was entitled to only 4 instead of 9 Congressmen, who were elected at large. ${ }^{2}$ Thus the plaintiff sought to force the State of Virginia to either lose 5 of its Congressmen for its failure to comply with the 14th Amendment, or to force the State of Virginia to permit Black as well as White citizens to run for elected office and be entitled to its full quota based on the total male population. The Court's opinion reads:

"It is well known that the elective franchise has been limited or denied to citizens in various states of the Union in past years, but no serious attempts have been made by Congress to enforce the mandate of the second section of the 14th Amendment, and it is noteworthy that there are no instances in which the Courts have attempted to revise the apportionment of Representatives by Congress." 3

New York State, like the States below the Mason-Dixon Line, had its own method of disenfranchisement - special property qualifications. The 14th Amendment did confer citizenship on the Afro-American as a citizen of the United States, but not in the State in which he resided.

1 McPherson v. Blacker, 146 U.S. 1 (1892).

${ }^{2}$ Saunders v. Wilkins, 152 F (2d) 235 (1945).

3 Op. cit., pp. 235, 237-238, citing Willoughby, Constitution, 2nd ed., pp. 626627. 
The above statement can be illustrated by offering in testimony sec. I of the 14th Amendment and the United States Supreme Court's interpretation of implied Congressional intent. It reads:

"All persons born or naturalized in the United States, and subject to the jurisdiction thereof, are citizens of the United States, and of the State wherein they reside..."1

However, in the Slaughter-House Cases, ${ }^{2}$ the Supreme Court offered the interpretation that:

"with the ratification of the 14th Amendment a distinction between citizenship of the United States and citizenship of a State was clearly recognized and established, not only may a man be a citizen of the United States without being a citizen of a State, but an important element is necessary to convert the former into the latter. He must reside within the State to make him a citizen of it, but it is only necessary that he should be born or naturalized in the United States to be a citizen of the Union. [Therefore], there is a citizenship of a State, which are [sic] distinct from each other, and which depend upon different characteristics of circumstances in the individual."

To a great extent the foundation for this opinion was established in 1857 , notably in the Dred Scott Case. ${ }^{3}$ In that case, Chief Justice Taney of the Supreme Court of the United States ruled that United States Citizenship was enjoyed by two classes of individuals:

(1) "white persons born in the United States as descendants of persons, who were at the time of the adoption of constitution recognized as citizens in the several states and [who] became also citizens of this new political body [the United States of America, and

(2) those who, having been born] outside the dominions of the United States, [had migrated thereto and been naturalized therein]."

Furthermore, Taney conceded that the States had the authority to confer State citizenship upon anyone in their territory, but could not make the recipient of such status a citizen of the United States. Accor-

1 14th Amendment, Sec. 1 (Italics added).

2 Slaughter-House Cases, 16 Wall, pp. 36, 74 (1873).

3 Scott v. Sandford, 19 How. 393 (1857). 
ding to Chief Justice Taney, however, the Afro-American was ineligible to attain United States citizenship either from a State, or by virtue of birth in the United States, even as a freeman descended from an Afro-American who resided as a freeman in one of the States at the date of ratification of the original Constitution. In other words, the Constitution of the United States did not envisage the possibility of Colored American citizenship ${ }^{1}$. However, the 14th Amendment rectified this deficiency by granting the Afro-American national citizenship. Since the Congress had no intention of reducing State representation because a State denied citizenship to the Afro-American, the ground work for denial of voting rights was laid. Ultimately the 14th Amendment did give each State the right, with some qualifications, to confer the vote to its citizens as interpreted in the MacPherson v. Blacker case. $^{2}$

"The right to vote intended to be protected refers to the right to vote as established by the laws and constitution of the State, subject however to the limitation that the Constitution, in art. I., sec. 2, adopts as qualifications for voting members of Congress, these qualifications established by the States voting for the most numerous branch of their legislature."

Previously, it was mentioned that the qualifications were abandoned for all practical purposes by the States without Congressional enforcement. Thus the political promises made to the Black American continued to be unfulfilled. On the question of Congressional intent, Horace Greeley ${ }^{3}$ held qualms similar to that of the Afro-American when he alleged that the Congress of the United States purposely deferred the suffrage issue to the States because they feared adverse Northern reaction to federal enactment of legislation making it mandatory for United States synonymous with State citizenship. (It is recognized that there are vital constitutional issues involved between State sovereignty and Federal jurisdiction.)

New York forced the suffrage question on the Southern States and on millions of incompetent ex-slaves, but denied the same to a few thousand Afro-Americans who were capable of exercising the right intelligently. In his annual message to the State Legislature in 1865, Governor Fenton expressed his opinion concerning Black suffrage in the South.

1 Ibid., pp. 404-406, 417-420.

2 McPherson v. Blacker, op. cit., p. 1.

3 Horace Greeley to James R. Lawrence, December 16, 1866 (Greeley Papers, New York Public Library). 
He stressed the duty of each State to throw its whole weight and influence firmly on the side of this fundamental requirement. He associated himself with all persons in the patriotic determination for "unity and the Constitution". ${ }^{1}$ Thus while there were many sincere believers in universal manhood suffrage, the power structure continued to ignore the issue. For example, in 1865, New York State Republicans' platform ignored the suffrage issue; ${ }^{2}$ the Nere York Tribune summarized the attitudes of many Northern politicians on the suffrage issue as those

"who desire the Right of Suffrage for the Blacks in the South [are] opposed [to] the extension of the same right to the Blacks in the North."3

On the suffrage question, Dr Fishel ${ }^{4}$ revealed the non-apathy of many Afro-Americans by contending that race leaders sought relief in universal manhood suffrage from 1865 until ratification of the 15th Amendment in 1870. Understandably, after the Civil War as well as before, and in New York no less than elsewhere, political suffrage was espoused mainly by Afro-American politicians, intellectuals, professionals, Afro-American conventions, newspapers and at local meetings. The audiences were primarily Afro-American with a sprinkling of Whites. These audiences, aside from a hard core, were ever changing in composition. Perhaps the lack of mass support was one of the factors why New York Afro-American petitions to the delegates of various State Constitutional Conventions pleading for universal manhood suffrage met without success.

There were "soul-brothers" outside the Afro-American community, and among these were included some outstanding politicians, newspaper and magazine editors. One White Soul Brother, Wendell Phillips addressed the Anti-Slavery Society at Cooper Union Institute in May of 1865. During his address, he suggested that the Constitution of the United States be amended to read:

"No State shall make any distinction in civil rights among the people born on her soil, of parents permanently resident, on account of race, color, or descent."5

1 Anti-Slavery Standard, January 7, 1865.

2 New York Independent, November 2, 16, 1865.

3 New York Tribune, December 14, 1865.

4 L. Fishel, Jr, "The Negro in Northern Politics, 1870-1900", in: The Mississippi Valley Historical Review, Vol. XLII, No 1, June 1955, p. 468.

5 New York Herald, May 18, 1865. 
Editorials in various newspapers sympathized with Phillips' suggestion. In essence they contended that the Afro-American was no longer a slave; he had acquired the title to rights of manhood and not only was he entitled to this right because he was native to our soil, but because there were thousands of Afro-Americans throughout the country who were fully qualified by training and experience to exercise the right of franchise. ${ }^{1}$ Notwithstanding these instances of individual White support, the voters of the State of New York continued to deny the Afro-American the right of equal suffrage with that of naturalized immigrants.

Prior to and after the Civil War, various Afro-American leaders, like Frederick Douglass, continued to exhort the public with speeches throughout New York and New England to enlist their support for the cause of universal manhood suffrage. Douglass, a runaway slave, self-educated, publisher of Northern Star (name later changed to Douglass' Weekly), was implicated in John Brown's raid on Harper's Ferry, served as Minister to Haiti during President Grant's administration, and was a staunch Republican politician. On April 17, 1865, in the City of Boston, Douglass gave a speech before the Massachusetts Anti-Slavery Society, a predominantly white organization, wherein he emphasized the point that "taxation can only go with representation", and since the Afro-American paid his taxes, fought for his country then, "He knew enough to vote on good American Principles."2 In conclusion, Douglass mentioned that only three times in American history was the Afro-American considered a citizen, each time during a war-period - 1775, 1812, and again in 1865 - at all other times the Black American was considered an alien. ${ }^{3}$

On June 2, 1865, Douglass spoke again on the future of the Colored Man before a mixed audience in New York City. This time he attacked New York State's politicians because they had refused permission to Afro-Americans to march in the Lincoln funeral procession. ${ }^{4}$ During the June 2nd meeting in New York, Douglass made the point that "slavery had been abolished forever - now we have no North, no South, no East, no West in American politics, but [we do have] one nation of all and for all."5

1 New York Times, June 7, 1865; New York Herald, June 12, 1865.

a Annual Meeting of the Massachusetts Anti-Slavery Society, "What the Black Man Wants" (Boston, April 17, 1865), p. 37.

3 Ibid, p. 29.

4 New York Times, June 2, 1865 ; New York Times, April 24, 1865. Apparently, various New York Afro-American societies including Black chapters of the Free Masons had sought in vain permission to march in the Lincoln funeral procession from the Committee of Common Council.

5 New York Times, June 2, 1865. 
Another vocal Afro-American leader was the Rev. Henry H. Garnet, who obtained his primary education in New York City's African Free School, No. 1, and took his advanced education in theology at Oneida Institute. Upon graduation from the latter school, he was licensed to preach the gospel. Garnet did hold the pastorate at Shiloh Presbyterian Church in New York City for almost a half a century. In an address entitled, "The Restoration of the Rebel States and the Claims of the Black Man", before a group at Cooper Union Institute in New York, he enunciated three points worth repeating. They were: (1) The Afro-American was liberated by the Civil War and he, as an American Citizen, was entitled to vote. (2) The Afro-American was as intelligent as the immigrant who came to this country; the latter, usually, ignorant of our culture and our history; on these grounds alone the Afro-American was equally qualified as the white immigrant to the franchise. (3) Furthermore, the future stability of the Republic depended upon the extension of universal manhood suffrage to all citizens. ${ }^{1}$

Supplementing the efforts of individual Afro-Americans, concerted Afro-American action manifested itself in numerous conventions and memorials held throughout the State. On November 9th, 1865, one such convention was held at Poughkeepsie, New York. ${ }^{2}$ This body of Afro-American representatives agreed to finance a delegation to seek an audience with President Andrew Johnson. Among those included to represent the Colored Man were, George T. Downing, and Frederick Douglass. They were granted an audience on February $6,1866 .^{3}$ Downing, after paying his respects to the President, stated that the purpose of the delegation was to obtain equality before the law in all States. ${ }^{4}$ Douglas continued to embellish the delegation's case by presenting arguments similar to those he had stressed at the Massachusetts Anti-Slavery Society's Convention the previous year. ${ }^{5}$ President Johnson listened sympathetically, but responded in the negative. ${ }^{6}$ To assuage the delegation, Johnson contended that he had always been a friend of the Colored population but could not adopt a policy which would end in a contest between the races.(2) He answered

1 New York Times, June 25, 1865.

2 American Annual Cyclopaedia and Register of Important Events (N.Y., 1865), p. 615.

3 E. A. McPherson, Handbook of Politics for 1868 (Phillips and Solomon, 1868), p. 52.

4 Ibid.

5 Ibid. p. 53.

- McCall, op. cit., pp. 257-264. The rupture between the majority of the Republicans the President with regard to reconstruction was partially revealed when Stevens resolution to form a joint committee on reconstruction to inquire into the condition of the Southern States was carried by 133 to 36. 
the query on universal manhood suffrage by saying that, "suppose by some touch of magic, you could say to everyone, you shall vote tomorrow, how much would that ameliorate their condition at this time?"1 (3) He further pointed out that they were both anxious to accomplish the same ends, "but that they proposed to do so by following different roads."2

In New York State there were some white politicians who did plead the Afro-American's cause. One member of this group was Senator O'Donnell. In 1866, Senator O'Donnell reintroduced resolutions previously pigeon-holed by his colleagues. ${ }^{3}$ O'Donnell could even claim a degree of success for his program since both houses of the State Legislature adopted several of his resolutions. However, resolutions are not laws, and like their predecessors, these measures followed the old pattern - tabled into extinction. ${ }^{4}$

Despite these set-backs, Black Americans continued to have faith in the democratic process by believing that the dominant group, in time, would rectify the existing inequality - the granting of universal manhood suffrage to all persons regardless of color... Many Afro-Americans displayed this faith when they summoned meeting after meeting in their effort to pressure the establishment into taking positive action. To wit: On June 6, 1866, ${ }^{5}$ some New York Colored Americans met and discussed the proverbial question: How can Afro-Americans obtain equal franchise qualifications? Numerous suggestions were offered by the audience; a distillation of these suggestions revealed at least one consensus: every American citizen had the right to vote by virtue of his national citizenship. Since citizenship gave a person the right to vote, then it was inherent in the basic principles of the constitution of the United States, and any denial of this basic right was contrary to the Bill of Rights (the first ten amendments to the Federal Constitution). If this contention was denied, it was an appropiate issue for the Supreme Court of the United States to decide. To insure wide-spread propagation of the issue, a Council of Fifteen was elected. Election of the Council was the first step; the second step was the group's agreement to raise funds to permit initiation of legal proceedings, if necessary to carry the matter until the judicial process was exhausted.

There were more radical groups who felt that direct political action was the answer and that legal proceedings would prove nugatory. To substantiate their position, they did offer historical references. In

1 E. A. McPherson, op. cit., p. 53.

2 Ibid., pp. 55-56.

3 Ibid.

4 American Cyclopaedia and Register of Important Events (N.Y., 1866), p. 544.

5 New York Times, June 6, 1866. 
1866 , this politically oriented group held a convention in Syracuse, New York and attempted to reconstruct the Union Party of 1862.1 This new party platform advocated the support of a Congressional Plan which would exclude any and all Southern States from the Union until Congress and the States' legislatures extended universal manhood suffrage to all Afro-Americans.

The Union Party had come into existence in 1862, a year after the Civil War had started. It arose because of the reappearance of opposition to the Federal administration under the name of Democratic Party. That there was need for a new party which could unite both the War Democrats and Republicans was amply demonstrated by the state and congressional elections of $1862 .^{2}$ This led Thurlow Weed, a Republican to summon a convention at Syracuse in 1862 at which time the Union Party was officially named. ${ }^{3}$ The party's primary purpose was to maintain the integrity of the Union at all costs and was well described by the convention's temporary chairman.

"I see before me not only primitive Republicans and primitive Abolitionists, but I see also primitive Democrats and primitive Whigs... primitive Americans... As a Union Party I will follow you... to the gates of death; but as an Abolition Party, as a Whig Party, as a Democratic Party, as an American Party, I will not follow you one foot."4

The Party's two cardinal features - destruction of the Confederacy and passage of the 13th Amendment (abolition of slavery) - were achieved after the 1864 Convention. The reconstruction of the Union Party in New York was instigated by the fact that it was not until after 1866 that the Afro-American suffrage question was fully developed as a part of the Radical movement. ${ }^{5}$

On October 23, 1866, a third variation for the attainment of universal manhood suffrage was enunciated at still another Colored Convention held in Albany, New York. This body was credited with being, "on the whole, the most sensible body of its kind which had yet met..." Speeches made at this Convention and at various places throughout the State were so temperate and "intelligent" that the group's moderate

1 New York Times, September 8, 1866.

2 W. A. Dunning, "The Second Birth of the Republican Party", in: American Historical Review, XVI, p. 56.

3 A. C. Flick (ed.), History of te State of New York (N.Y., 1935), VII, p. 111.

4 Dunning, op. cit., p. 57.

5 Ibid., p. 61. 
treatment of public issues exemplified the "conservative politics of the State of New York", on the suffrage question. ${ }^{1}$

A fourth variation on the theme: how to attain universal manhood suffrage was the suggestion of a merger with other minority groups. On November 19, 1866, ${ }^{2}$ in New York City such a convention was called to press for equal privileges for all in the eyes of the law. The convention's rooster included such names as: Mrs Elizabeth Cady Stanton, Mrs Susan B. Anthony, Frederick Douglass, et al. Many persons in the audience were startled to learn from John Bright that only threeeights of all adults could vote and that five-eights of the country's adults, including women and Afro-Americans, were denied this right. Mrs Stanton stated that "as we are now agitating the question of suffrage for the Colored Man, we should do so for the women." Mrs Elizabeth Jones presented one resolution to the effect that the right to suffrage was the only possible security one can have and that the denial of this right to the Afro-American was only a consequence of slavery. ${ }^{3}$ Douglass pleaded for the right of women to vote, for a coalition between Afro-Americans and women members of the American Equal Rights Association, and he requested that the women take the Colored American by the hand to elevate him. He thought that these vocal women could exert some pressure on the delegates to New York State's 1867 Convention.4 Pillsbury, a White advocate of equal suffrage, in addressing the American Equal Rights Convention, paraphrased Thomas Jefferson and echoed Douglass when he contended that all who fight and pay taxes have the right to suffrage. Pillsbury toned down the importance of the women equalrighters when he stated that equal suffrage was more important to Colored Americans than to women. ${ }^{5}$

Even when the New York Afro-American held the special property qualifications for voting, he, frequently, discovered that some politicians devised ways of stripping him of his potential political power. To wit: the New York 1866 law, $^{6}$ which stated that the name of no person (theoretically this applied to all potential voters), should be placed on the register unless that person appeared personally before the Board of Registrars during a registration period as prescribed by the law. (This law covered the cities of New York and Brooklyn where the bulk of New York State's Black population resided. The City of Brooklyn

1 New York Times, October 23, 1866.

2 New York Times, November 20, 1866.

3 Ibid.

4 New York Times, November 23, 1866.

${ }^{5}$ New York Times, November 22, 1866.

- Laws of the State of New York, 1866, Ch. 812, Sec. 7. 
was incorporated into New York City in 1890.) Prior to passage of this law, it was common practice to copy the previous year's list. The legality of the law was challenged on November 22nd 1866 in New York's Supreme Court. The legal issue was whether or not members of the Board, when registering voters, should determine solely on the basis of skin color whether a voter was an Octroon, Quadroon, Mustee, - or an African. ${ }^{1}$ To be eligible to vote, under the 1866 law, Africans had to hold prior ownership of a $\$ 250.00$ freehold; residence requirements were the same for all citizens.

A product of a mixed alliance, miscegenation, James Darnall decided to contest the constitutionality of the 1866 law when he obtained a court order to show cause why the Board of Inspectors of Registry and of Elections of the Second District of the 18th Ward of New York should not place his name on the register. When the Board failed to comply with the Court's order, the State's Supreme Court issued a temporary Writ of Mandamus. ${ }^{2}$ During the legal proceedings, Attorney Gilbert, representing the Plaintiff, informed the Court that his client was as White as any member of the Bar then practicing before the Court. Defense Council objected and countered that Darnall was denied his right to register because he was an African. In an effort to clarify the issue in this case, the presiding justice posited the question: "What criteria should be used to determine when a man was an African?" Plaintiff's attorney suggested that this question be left to a jury to decide. $^{3}$ The case was adjourned until November 26, 1866 and when it was reopened, the Board's counsel submitted two additional statements as to why the plaintiff's plea should be denied. They were (1) Darnall failed to present himself as an African, and (2) Darnall, being an African, had not owned a freehold of $\$ 250.00$ since November 6,1865 ; hence he was ineligible to be placed on the registry. ${ }^{4}$ The Court never rendered a decision in this case.

The suffrage status of the Blackman, in most Northern States, was summarized as follows:

“... neither in this state [New York], nor in Pennsylvania, nor in Ohio, nor in Indiana, nor in Illinois has Negro suffrage been generally presented as an article of party faith. On the contrary, in each of these States, the Constitutional Amendment [13th Amendment] has been approved as an official embodiment of terms presented by the victorious North to the defeated South."5

1 New York Times, November 23, 1866.

2 Ibid.

3 Ibid.

4 Ibid.

5 New York Times, November 28, 1866. 
The New York Afro-American who had been granted equal suffrage by New York State's 1777 Constitution, lost it in 1821, now placed his faith in the 1867 Constitutional Convention. The 1846 revised State Constitution made it mandatory that every 20 years there be a constitutional revision. This placed the next Constitutional Convention for June 4, 1867. Even though the State's Constitution had been amended in 1845, 1857, 1859, and again in 1860, the Afro-American's petitions during these years for equal suffrage had been by-passed. ${ }^{1}$ By 1867, Colored Americans felt that the post-Civil War Climate was ripe for such a change, that is the eradication of the required $\$ 250.00$ freehold prescribed only for the Blackman. Amid the proceedings and debates of the 1867 Convention, another petition was prepared by Dr W. H. Johnson, Chairman of the State Central Committee of Colored Citizens. This petition, pleading for the establishment of equal manhood suffrage, was submitted to the Convention's Committee on the Right of Suffrage which was chaired by Horace Greeley. ${ }^{2}$ On June 28,1867 , Greeley submitted the committee's recommendation to the full convention, which stated that all discrimination based on color should be eliminated since all races are governed by the same State laws. Furthermore, the recommendation suggested the incorporation of these views into the revised State's Constitution. ${ }^{3}$ Even though the Republican delegates at the Convention were committed to the franchise issue, and even though they held a majority of 14 , the committee's recommendation led to a protracted debate. ${ }^{4}$ It was the Democrats who opposed Afro-American suffrage and they sought to have the question submitted to the voters on a separate referendum. Although the Republicans recognized the strategy of the Democrats, aiming at ultimate defeat of the suffrage issue if submitted on a separate referendum, and stood for inclusion with the total constitution, debate stymied the Republicans from having their way. In the end the Radical Republicans managed to push through the revised constitution, including the Afro-American franchise question, at least through the State Assembly, but the State Senate refused to accept the franchise as part of a total package. ${ }^{5}$ This impasse resulted in a recess from September 24, 1867 until November 12,1867. Obviously, this took the franchise issue out of the election that year. Republican failure to incorporate the

1 Flick, op. cit., p. 105.

2 W. H. Johnson, Autobiography (Albany, N.Y., 1900), p. 70.

3 Documents of the Convention of the State of New York, 1867-1868, (Albany, N.Y., 1868), I, pp. 2, 282.

4 Proceedings and Debates of the Constitutional Convention of the State of New York (Albany, N.Y., 1868), I, Pp. 200-263, V, pp. 3560-3586.

5 Ibid., I, p. 289. 
Afro-American issue on the ballot of the November, 1867 election proved a favorable political issue to the Democrats. ${ }^{1}$

Finally, on February 27, 1868, both parties reached a compromise on the question of how the universal manhood suffrage should be presented to the voters. Both parties agreed to submit the question to a referendum; the latter was in fact merely a resubmission of Sec. 1, Art. 2 of the 1846 Constitution. ${ }^{2}$ The referendum requested the voters to decide whether the $\$ 250.00$ freehold should be eliminated as a requirement for Afro-American suffrage. ${ }^{3}$ In the November 1869 election, the voters refused to remove the $\$ 250.00$ freehold clause from the State Constitution. This denial of equal suffrage rights to the AfroAmerican was an expression of prejudice, a prejudice which revealed the "second-class" status of New York's Colored population. Deep-rooted "racism" was exemplified in New York State's 1869 election. Citizens displayed their displeasure with the Republicans when they rejected the newly revised constitution and put the Democratic slate into office. ${ }^{4}$ Upon taking office the Democrats proceeded to rescind their predecessors' approval of the 15th Amendment. ${ }^{5}$ It was only after three-fourths of the states had ratified the 15th Amendment in 1870 that New York State's Colored population was assured of obtaining the franchise on an equal basis with Whites. ${ }^{6}$

RESTORATION OF EQUAL SUFFRAGE

Instrumental in opening debate on the 15th Amendment in the State legislature was the State's Committee on Federal Relations recommendation to ratify the 15th Amendment on March 17, 1870. In principle, the Democrats questioned the giving up of a State Right the right of the State to control the elective franchise. The original resolution was adopted along party lines on April 14, 1870.7 Still it took a State Constitutional Commission, in 1873, to transmit an amendment to Sec. 1, Art. 2, to erase the property qualification from

1 New York Independent, August 1, 1867; D. C. Alexander, Political History of the State of New York (N.Y., 1909), III, pp. 185-186.

2 Documents of the Convention of the State of New York, 1867-1868, pp. 11811182.

3 Ibid.

4 American Annual Cyclopaedia (N.Y., 1870), pp. 486-490.

5 New York Times, March 18, April 15, September 23, December 8, 1869.

6 New York Times, April 22, 1870.

7 E. MacPherson, The Political History of the U.S. of America during the Reconstruction (2nd ed., Washington, D.C., 1875), pp. 551-562. 
the State's constitution. ${ }^{1}$ The latter was passed during the general election of November $3,1874 .^{2}$

Whereas the 14th Amendment offered the Afro-American national citizenship, it failed to bestow upon him state citizenship and the right to vote. Section 1 of the 15th Amendment sought to rectify this inequity. It reads:

"The right of citizens of the United States to vote shall not be denied or abridged by the United States, or by any State on account of race, color, or previous condition of servitude, [and Sec. 2, like that of the 14th Amendment, gave] The Congress the power to enforce this article by appropiate legislation."

However, the Supreme Court of the United States, in its initial appraisal of the 15th Amendment was inclined to emphasize only the negative aspects. Thus,

"the 15th Amendment did not confer the right [to vote] upon anyone, [it did merely] invest the citizens of the United States with a new constitutional right which is ... exemption from discrimination in the exercise of the elective franchise on account of race, color, or previous condition of servitude."3

On April 27, 1870, the New York State Legislature did pass an act to amend the law relating to elections. This law did repeal the property oath for Colored voters; it, also, provided for a uniformity of oaths and abrogated the registry law requiring a special form of oath for Afro-American voters. Furthermore, the law provided that all existing laws and parts thereof which directed registrars and inspectors of elections to require Colored voters to take the oath were to be abolished. Also the interrogation of Afro-American citizens or their witnesses was to be done away with, and the act, finally, made it unlawful to administer any oath to Afro-Americans that was not required of other citizens. To enforce the intent of the law, any inspector who failed to comply with the new law would be guilty of a misdemeanor, punishable by a fine of $\$ 500.00$ and/or 6 months imprisonment. Although this act was to take effect immediately, ${ }^{4}$ it was not a constitutional amendment since the voters had not voted on it.

1 "The Constitutional Commission, 1872", in: Political Science Quarterly, IV, June 1889 , pp. 240-241, 258.

2 Alexander, op. cit., p. 320.

3 U. S. v. Reese. 92 U.S. 214, 217-218 (1876); U. S. v. Cruikshank, 92 U.S. $542,556(1876)$.

4 Laws of New York (1870), p. 922. 
Afro-American reaction to the 15th Amendment ran the gamut. On the national level, Frederick Douglass, a staunch Republican, for political reasons eulogized his Party when he alleged that the Republicans instigated the enactment of the amendment. "It was in such humane acts that the glory and grandeur of the Grand Party lies." 1 In retrospect, an Afro-American political scientist, described the 15th Amendment as a shift from the State's right document prior to the Dred Scott Decision, to one of a new charter of liberty with the shift of power to the Federal government. ${ }^{2}$

At the other extreme was the cautious reception by $\mathrm{Dr}$ W. H. Johnson, a leader in New York's struggle for equal suffrage. His skepticism was revealed when he requested a legal opinion from New York State's Attorney General. ${ }^{3}$ For a number of years, Dr Johnson was indentified with the Republican Party; he left the party after having some difficulty with Republican leaders over passage of the 1866 Civil Rights Act. Although he aligned himself with the Democrats for a while, he did not hesitate to criticize both political parties. ${ }^{4}$

On April 9, 1870, Dr Johnson wrote to Attorney General Peckham requesting legal clarification of the following:

(1) "Is the 15th Amendment ratified?"

(2) "Does it confer the franchise upon Colored Citizens?"

(3) "Is it the right of Colored Citizens of this city (New York) to be registered with a view to voting on next Tuesday?"

The attorney-General's Office was prompt in responding in the affirmative on all of the above questions; its head concluded his letter with the comment that inspectors who failed to comply were subject to a fine and/or imprisonment. ${ }^{5}$

During the early 1870's some political change permeated the municipal scene. Political change was initiated by the New York Times' 6 disclosures of Boss Tweed's nefarious manipulations of municipal spending. The New York Times' disclosures were complemen-

1 F. A. Bailey (ed.), The Life and Times of Frederick Douglass (N.Y., 1941), appendix I, pp. 649-650.

2 E. L. Tatum, The Changed Political Thought of the Negro, 1915-1940 (N.Y., 1951), p. 76 .

3 W. H. Johnson. op. cit., pp. 94-95.

4 Ibid., p. 214.

5 Ibid., p. 68.

- Unless otherwise stated this section of the paper is based on articles and editorials in the New York Times for the period July 8, 1871 through Feb., 1872. 
ted by Thomas Nast's cartoons in Harper's Weekly. ${ }^{1}$ The city on the verge of financial bankruptcy saw a mass meeting held at Cooper Institute on September 4, 1871, resulting in the appointment of the Committee of 70 . This Committee aided in the passage of a new charter for New York in 1873. Although the new charter was a compromise between the Committee of 70 and Republican politicians, it did offer a semblance of equal rights and representation for all. Now a minority of voters could enjoy increased representation in the unicameral Common Council. Three aldermen were to be selected annually from each of the municipality's five senate districts. Each voter was restricted to voting for only two candidates, and six additional aldermen were to be elected at large and each voter restricted to choosing four. ${ }^{2}$ Its purpose accomplished, the Committee of 70 went out of existence on October $23,1873 .{ }^{3}$

\section{THE EMERGENCE OF POLITICAL RECOGNITION}

Those Afro-Americans who had the vote, before 1870 as after, tried to pit one party against the other in an attempt to gain political perquisites from both parties. During the post-bellum period, John A. Nail, a leading citizen of his community organized a Colored American Democratic club in New York as early as 1868. (This Democratic club had a continuous existence from its initiation until well into the 1940's). ${ }^{4}$ Also there was the instance of Dr W. H. Johnson who left the Republican Party and temporarily pledged allegiance to the Democratic Party in the late 1860's. Following ratification of the 15th Amendment, political recognition became more prominent with the increase of Afro-American eligibles. Thus at the Republican State Convention held in Troy, New York on May 8-9, 1872, rival factions agreed to send a Colored delegate at large from the State of New York to the National Republican Convention in Philadelphia. ${ }^{5}$

New York State's Republican Convention choose Frederick Douglass as their delegate at large and instructed him to deliver a certified statement of the state's delegates votes for the Republican nominee. ${ }^{6}$ Although Douglass had on more than one occasion alleged that the party had neglected the Afro-American in politics, he continued to

1 Harper's Weekly, July 22, 1871.

2 Laws of New York (1873), ch. 335.

3 New York Tribune, October 23, 1873.

4 C. McKay, Harlem: Negro Metropolis (N.Y., 1940), pp. 124-131.

5 Amerian Annual Cyclopaedia ... (Albany, N.Y., 1872), pp. 585-586.

- W. J. Simmons, Men of Mark, Eminent, Progressive and Rising (Cleveland, 1887), p. 73. 
embrace the party's ideology with great emotional intensity. His political fervor was revealed when he stated that "I would rather be with the Republican Party in defeat, than with the Democratic Party in victory."1

The majority of the north's Afro-Americans continued their loyalty to the Republican Party, but there were many disillusioned Colored Americans who defected to the Democratic Party. ${ }^{2}$ To reiterate, there was Dr Johnson who felt that some Republican leaders had let the Afro-American down by not supporting the 1866 Civil Rights Act. There were others like George T. Downing who felt that the party did not accord the Colored American sufficient patronage; Peter Clark felt the same way. ${ }^{3}$ James $C$. Matthews, a very able lawyer whose legal suit against the City of New York opened the White schools to AfroAmericans, cast his first ballot for General U.S. Grant and remained a strong supporter of the Republican Party until 1872. Judge Hamilton ascribed the shift from the Republican Party to that of the Democrats when he stated that "...In keeping with the ideas ... which drove so many of the best men from the Republican Party in 1872, he [Matthews] joined the liberal movement in that year, and attended the Liberal National Convention as a delegate."4

Though aware of the Afro-American's political power, through equal suffrage, many Colored American leaders were unable to unite Black voters into a force capable of extracting the full benefits from the politicians. George T. Downing contended that the power of the ballot in this country should not be overlooked by the Afro-American. If it had been more generally exercised, its effect would be very perceptible. ${ }^{5}$

Ever on the alert, the politicians managed to circumvent the principle of minority representation incorporated in the revised City Charter ${ }^{6}$ by the use of gerrymander. ${ }^{7}$ On June $8,1874,{ }^{8}$ an act to amend the amended Sec. I of Art. II of the City Charter, referred to earlier, in relation to elections in the City and County of New York was

1 Ibid., p. 79.

2 New York Times, September 9, 1875.

3 New National Era, December 18, 1873; Bee, March 14, 1885.

4 Simmons, op. cit.

$5 \mathrm{~W}$. W. Brown, The Rising Son: or the antecedents and advancement of the Colored Race (Boston, 1874), p. 253.

- Laws of New York, (1874), p. 925.

7 Gerrymander is to alter the political map of, as a State, or County, so that the voting districts are unfairly, or abnormally arranged, for the purpose of advancing the interests of a particular party, or candidate. To wit: "Mr. McKinley ... was warmly supported by the popular vote, gaining considerably in his district, and he was defeated only by a gerrymander." C. W. Curtis, Harper's Weekly, March 28, 1891.

8 Laws of New York, op. cit. 
passed. This act contained a provision for the redistricting of the City and County and for the change either, in number of, or boundaries of any election district. On June 12, 1874, the City of Brooklyn passed a similar act. Under these acts, the cities of Brooklyn and New York were to be redistricted and election inspectors were impowered to challenge any person listed as a qualified voter until he had taken an oath that he was a bona-fide voter in that district. Challenges proved plentiful in both cities.

Believing that the Afro-American was wedded to the Republican Party, the Democrats pressed for passage of the redistricting act. The latter's belief was based on the voting pattern of the Colored and on the strong statements made by such Afro-American leaders, as Douglass. For example, "The Republican Party is the ship, all else the sea..."1 On September 17, 1867, the Colored Republican Committee of New York informed the Colored voter that they enjoyed the rights of American citizens under the Constitution only because of the Republican Party; this party stood for "free schools, free speech, hard money and universal suffrage". ${ }^{2}$

On the other hand, the Republicans did not object too strenuously, since they felt assured of the Colored vote and that redistricting might even gain them some White votes. The loss of power in given districts would mean less need for passing out political patronage to the AfroAmerican and could be used to bolster the White segment of the party.

In the process the emergence of political power in both a positive and a negative sense was revealed. On the positive side the AfroAmerican did obtain equal suffrage rights, but his failure to unite behind his own leaders meant that he could not extract as much as possible from the social structure as would be the case under a united banner. Certainly, Afro-Americans by pitting one party against another, shifting allegiance from Republican to Democratic and often back to the Republican Party, did so with a view toward extracting political patronage, and sometimes with success. But these tactics might favor their opponent's chances to curtail the real impact on elections by utilizing the gerrymander.

\section{EQUAL VOTING RIGHTS BUT UNEQUAL STATUS}

Using his experience, during the post-bellum period, the Afro-American decided that the best strategy to obtain status equal with his resurgence of universal manhood suffrage was to attack the Republican Party

1 Bailey, op. cit., pp. 477-491.

2 New York Times, September 17, 1876. 
from within and to continue to pit one party against the other for the Black vote. These tactics were to reveal the pragmatic intentions of both parties toward the Black American and were to gain him additional political patronage.

Although many Afro-Americans consistently voted the Republican ticket, it was felt by some that the party had failed to carry out its pledges. One articulate observer sent a letter to the editor of the New York Times reminding the party that:

"Politically, I am a Republican. My first vote was cast for Fremont and my last for Hayes; socially, I am a 'Colored American Citizen'. Why talk of obliterating the color line in politics while the cause of it remains intact! To enable the Negro to occupy the status which the Constitution accords him, the Negro needs the aid and protection of wise laws, humanely administered through the influence of a public conscience - of that rare power which is the product of rising intelligence. There is only one resource left to the Negro, and that is to abandon the [Republican] party, that betrayed him, then to go to the Democratic Party. Finally, the Negro question is not one of politics, but one of human rights, of organic law, and the preservation of the spirit, as well as the form of republican government."3

To some extent the above letter foreshadowed that most of the Republican platforms, those adopted between the years 1877 and $1885,{ }^{2}$ which endorsed equal civil rights, theoretically a concomitant of equal suffrage, were meant to hold the Afro-American loyal to the Republican Party, rather than to be fulfilled in practice. Even Douglass, a loyal party man and one who gained much personally from the party had some harsh things to say about the politicians' failure to extend civil rights beyond equal suffrage.

"... out of the depths of slavery has come this color line. It is broad enough and black enough to explain all the maligning influence which assailed the newly emancipated millions today. ... In one breath they tell us that the Negro is weak in intellect, and so destitute of manhood, that he is but the echo of designing white man. ... On the other hand, the whites virtually tell the Negro that he is so clear in his moral perceptions, so firm in his purpose, so steadfast in his convictions, that he cannot be

1 New York Times, November 3, 1876.

2 American Annual Cyclopaedia ..., 1878, p. 623; Tribune Almanac, 1883, p. 42. 
persuaded by arguments, or intimidated by threats, and that nothing could restrain him from voting for the man and measures that he approved." 1

In reviewing the political status of his brethren, for the decade of the 1870's, an Afro-American newspaper editor suggested that (1) the only way the Colored man could establish his rights was by using his vote wisely, and (2) that the Black leaders take over the power from white wardheelers.

"Here in New York where the White wardheelers have controlled our vote ever since the war, what have we to show for it? These white heelers have made millions of dollars and a widespread notoriety which we cannot call fame, but what have the colored voters gained? The same is true of Boston, Providence... Not one blackman in New York State enjoys the respect and confidence of the Republican politicians, or can they approach one of these sharpers on terms anything like an equal footing. And this may apply to the colored leaders throughout the country in their relations to the National Republican Party."2

However, despite various allegations made against the Republican Party's leadership by articulate Afro-Americans, the majority of registered Colored Americans remained loyal to the party on the national level. ${ }^{3}$

Vocal and articulate declamations made by Colored spokesmen did make some inroads on the Republican State Committee when they met in New York on March 4, 1884. These convention delegates declared that equal civil rights should be maintained, that the franchise should be respected, and that each voter should have a free ballot which would be counted honestly. Again at the 1885 Republican State Convention it was reiterated that it was unlawful to deny equal civil rights to Colored Americans. ${ }^{4}$

Recognizing the vocal discontent with the Republicans, a type of "tokenism" was used as politically expedient. Thus Afro-Americans, like Douglass, Dr W. H. Johnson and others were accorded honors considered exceptional to men of color. Dr Johnson was elected State Committeeman-at-large, and re-elected to the same post in 1888. These Black symbols proved politically remunerative since it did sway some

1 F. Douglass, "The Color Line", in: North American Review, June 1881, p. 573.

2 New York Freeman, November 28, 1885 (Italics added).

3 New York Tribune, December 14, 1886.

4 Tribune Almanac, December 14, 1886. 
25,000 registered Black Republicans to vote the party ticket about 90 percent of the time. ${ }^{1}$

Despite Republican "tokenism", there was further evidence of dissatisfaction with the Republican Party during the 1880's. For example, Downing made a complete break with the Republican Party in 1883. His change of political loyalty was based on conversations he had with some leading Northern Democrats. The latter convinced him that the Democrats both believed and practiced racial justice. In part, Downing's political philosophy was built on competition between the parties; this competition would give greater political recognition to the Afro-American. To wit: Downing thought that if more than one party was concerned, then they would cherish the hope, at least, that they could obtain part of the Afro-American vote. ${ }^{2}$ Timothy Thomas Fortune, a staunch Republican and leader in the Afro-American community, advocated a political philosophy similar to that of Downing. T. T. Fortune told his political audience that their activity should be based on the motto: "Race First, and then Party."3

This philosophy of Race First began to have its impact on both political parties as early as 1884 , when Grover Cleveland won New York State's electoral vote by only 1,109 ballots. This foreshadowed the potential importance of Afro-American voting power in the State. ${ }^{4}$ In 1886, President Cleveland paid off his political debt when he appointed James C. Matthew's, an Albany Democrat to the post of Recorder of Deeds. ${ }^{5}$ The fees connected with this office were so sizable that the New York Times carried an article entitled, "Matthews' Great Bonanza". It contrasted Matthew's salary with that of the managing directors of the Democratic Party. Furthermore, the article stated that the combined salaries of the President's Cabinet Officers and his private secretary were less than what Matthews was earning in office. (It was shortly afterward that Matthews was recalled from his post.) ${ }^{6}$

Following Cleveland's narrow electoral margin in New York State, in the next election, 1888, the Democratic Party in New York made a concerted effort to win over the Afro-American vote. Democratic success may be garnered from the fact that the Democratic candidate for Governor carried the state by 19,000 votes and some 30,000 AfroAmericans voted for the Democratic governor in the 1888 election.?

1 W. H. Johnson, Autobiography ..., op. cit., pp. 19, 35, 157.

2 New York Globe, May 12, 1883.

3 T. T. Fortune, The Negro in Politics (N.Y., 1886), pp. 58-59.

4 The New York Age, August 25, 1888.

5 New York Tribune, December 14, 1886.

B H. Minor, The Story of the Democratic Party (N.Y., 1928), p. 361.

7 The New York State Cleveland League, Colored Citizens State Democratic and Independent Organization (N.Y., May 26, 1892), p. 11. 
In 1889 the Chapin Democratic Club was established to create a sentiment that would make the suffrage of the Colored Citizens more forceful and effective. It should also give expression to the fact that Afro-American voters were anxious to line up with any agency that would promise assistance in their struggle for simple justice, and a fair representation in public service.

Two Afro-American politicians controlled the Chapin Club and made their political presence felt through the club. They were Matthews and McCants Stewart. On October 27, 1891, McCants Stewart addressed the Club's members and prophesied that "the time would come when it would no longer be necessary for Afro-Americans to hold special political meetings." In his address, Stewart further stated that the political skies were clearing, that Afro-Americans were growing thoughtful in political discussion, and that they were dividing their forces in political action. Finally he stressed the point that some Afro-Americans were against the division of the vote; these people were Colored Republicans who clung to that party because it had emancipated and enfranchised them. Stewart contended that this was a partial truth. It should be remembered "in political discussion..., that in the Grand Army of the Republic, Democrats, as well as Republicans, fought side by side."1 To sway those Afro-Americans unconvinced of the "liberality" of the Democratic Party, Stewart claimed that over 40 colored persons were employed in the public service with an average salary of $\$ 10,000$ per annum. ${ }^{2}$ C. H. Lansing, Jr, President of the Club buttressed Stewart's claims when he stated that, "if, as I insist, the Democratic Party has been cooperating and a contributing force to bring about this desirable condition, I am sure, that with me you will applaud its liberality, and agree that it deserves the consideration of continued support."3

The Afro-Americans in New York continued to form organizations to uplift their welfare and to attain full American citizenship. One such organization, the National Relief Association had as its main purpose to secure the rights and privileges of Colored Americans. It was alleged that they had formed chapters in nearly every sizable city in the country and had enlisted the actual cooperation of nearly every prominent Colored man in the country. A call for a National Convention to be held in Washington, D.C., was scheduled for February 3, 1890.4 The purpose of the convention was to take remedial action especially

1 The Afro-American in Politics, an address by T. McCants Stewart, Esq. October 27, 1891, p. 6.

2 Ibid., p. 9.

3 The Address of C. H. Lansing. Jr. President of the Colored Citizens Chapin Club (N.Y., 1889), p. 5.

4 New York Tribune, October 11, 1889. 
in the Southern sections of the country where the political and civil rights of the Afro-American citizen were being denied, which was contrary to the Constitution of the United States. ${ }^{1}$

The political power held but not fully exercised by the Afro-American was noted in the New York Tribune, where it was contended that Colored citizens would realize enfranchisement by their own efforts, if only they were organized and directed wisely. The article was, in part, an attack on the poor leadership that existed in Black politics. It was further argued that Colored Citizens should gather themselves peaceably in those States, counties, or towns where they could be assured protection of these rights and to leave those places where they were not protected. Where they decided to reside, with assured protection, with the aid of a powerful organization, they could purchase property and become respected members of the community. The power of their vote in those areas, where they settled, would soon make their influence felt. ${ }^{2}$

During the 1894 Constitutional State Convention, neither party could use the suffrage issue as a political tool, as both parties had accepted, in principle, the suffrage right of the Afro-American back in the middle 1870's. To gain the Colored American's vote each party stressed the amount of political patronage it had dispensed to the Colored Community. Typical of politicians, each party claimed the complete allegiance of the Afro-American voter. Categorically, it may be stated that the majority of the Afro-American leaders still favored the Republican Party at election time. However, the bulk of the Colored voters did not always follow their leaders. ${ }^{3}$ Still the Republican Black Committees followed the standard line, eulogizing their party at the expense of the Democrats. ${ }^{4}$ The policy of extracting political patronage continued to exist by pitting one party against the other. Thus Jacob Sims, editor of the New York Echo (a Colored newspaper) who helped to organize the Afro-American Republican League in 1895 had his price for loyalty. Sims pressured the Republican leaders in New York to give more state and municipal jobs to the Colored. Like his predecessors in both parties, he argued that the Afro-American vote warranted such action. ${ }^{5}$

Once more in 1898 the Democrats felt optimistic, they thought that they would capture a sizable portion of New York's Afro-American votes. Again they miscalculated. This time Tammany Hall's hopes were

1 New York Tribune, December 19, 1889.

2 New York Tribune, December 10, 1889.

3 New York Tribune, October 28, 1894.

4 New York Tribune, July 4, 1895; October 20, 1898.

5 New York Times, July 10, August 17, 1895. 
shattered, in part, by the strong personality of their opponent's gubernatorial candidate - Theodore Roosevelt. Many Afro-American soldiers had served under his command in the Spanish-American War and many of them distinguished themselves as "Rough-Riders" in capturing San Juan Hill. Colored folk were indebted to him because he was instrumental in getting the Civil Service Commission to place persons in jobs based on qualifications rather than color. Roosevelt's speeches praised the Afro-Americans' achievement on the battle field and promised them to aim at equal opportunity in Government service. In fact, Roosevelt's attitude, as well as the agitation by many Southern Democrats against the Black man helped to win over the Afro-American clergy. ${ }^{1}$

Ever optimistic, in 1900 the Democrats thought they had the city's Afro-American vote in the palm of their hand but overlooked the New York race riot earlier in that year. The Democrats who were in local political control were held responsible for the police brutality exercised during the riot by leading Afro-Americans and some white newspapers. One newspaper went so far as to allege that many Dark Democrats were fleeing the party. ${ }^{2}$

\section{CONCLUSIONS}

It should be recognized that the Afro-Americans had won definite advantages, in the period 1870-1900: freedom, education and organization. However, they failed to capitalize fully on their political position. Moreover, it should be stated that these advantages were limited when compared with the progress made by the Whites. The New York Afro-American did reside in a state where the two party system offered him a vote, and certainly a greater power potential than in the South; yet, he failed to maximize his advantage. To ascertain the latter would have required united action so that he could break his ties, materially, ideologically, positively and negatively with the Republican Party. However, this united action never materialized because of "token patronage", corruption and political promises, promises continually renewed in campaign speeches, but rarely delivered in practice.

Of course, there were other basic reasons of the Afro-Americans' failure to acquire power in the existing political structure. (1) They were outnumbered; (2) They lacked the experience and resources to support a strong organization of their own; (3) They had a press which was subsidized by one party or the other - subsidies were curtailed or

1 E. E. Morison (ed.), The Letters of Theodore Roosevelt( Cambridge, Mass., 1951-1954), I, p. 357.

2 New York Post, August 21, 1900. 
stopped between election years, and this made for little or no continuity of an Afro-American press.

Most vital was the factor of racism: usually, New York State's laws proved ineffectual; the politicians neglected to grant the Afro-American full political and civil rights. Thus Afro-Americans were never fully accepted on a par with other men, only as "second class citizens". When Afro-Americans acknowledged their "second class status", they rationalized by using race as the basis and this rationalization came as an afterthought since the color line had previously been drawn by Whites. What program they did try to develop was based on a moral appeal. Finally, the turn of the twentieth century did see a mild break through since some Afro-American politicians gained occasional perquisites from both parties in order to hold, or to gain their allegiance. ${ }^{1}$

1 G. Osotsky, Harlem: The Making of a Ghetto (N.Y., 1966), p. 159. 